\title{
Use of vertical geothermal heat exchanger with nanofluid for heat supply systems
}

\author{
Alexei Sednin ${ }^{1}$, Aliaksandr Mukhin ${ }^{1,2}$, and Boris Balakin ${ }^{2}$ \\ ${ }^{1}$ Belarussian National Technical University, Minsk, Belarus \\ ${ }^{2}$ Institute of nuclear physics and engineering, National research nuclear university «MEPHI», Moscow, Russia.
}

\begin{abstract}
Future district heating systems need to be more flexible and move towards a carbon- neutral generation. Compression heat pumps are foreseen to be promising future tools for district heating systems in EU countries. The paper presents the simulation data or a vertical double-pipe geothermal heat exchanger with ethylene glycol- $\mathrm{Al}_{2} \mathrm{O}_{3}$ as a working fluid. To simulate the operation of the heat exchanger, the STAR$\mathrm{CCM}+\mathrm{CFD}$ application was used. It has been determined the optimal volume particle concentrations of nanofluid and enhance of heat exchanger performance.
\end{abstract}

\section{Introduction}

In many countries, there is a clear trend towards increasing variable renewable energy sources in the energy balance, primarily as an alternative to nuclear and coal energy. In particular, in the EU Northern countries, it is planned to completely abandon traditional energy sources by 2050 with the transition to renewable ones [1]. The spread of renewable sources is aimed to reduce gas, oil, coal consumption and to create more environmentally friendly installations [2].

One of the trends is implementation of heat pumps. Compression heat pumps are foreseen to be promising future tools for district heating systems in EU countries. Low-grade heat sources for the pumps have been categorized as follows $[1,3,4]$ :

- sewage water, temperature range $10-20{ }^{\circ} \mathrm{C}$;

- ambient water (sea, river), temperature range

$2-15^{\circ} \mathrm{C}$;

- geothermal sources, temperature range $9-55{ }^{\circ} \mathrm{C}$;

- flue gases, temperature range $34-60{ }^{\circ} \mathrm{C}$;

- industrial excess heat, temperature range $12-46^{\circ} \mathrm{C}$.

Fig. 1 presents a schematic diagram of a geothermal district heating system with heat extraction and distribution systems and heat pump [6].

Propane, propylene glycol in a concentration of 30 $35 \%$, ethylene glycol $30-35 \%$ are used as a working fluid for the heat extraction system [6].

The ethylene glycol coolant has a low freezing point, which is necessary for operation at negative temperatures and does not cause corrosion of the installation elements.

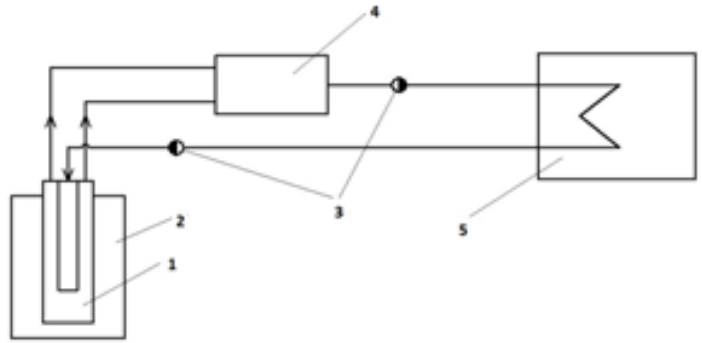

Fig. 1. Geothermal district heating system with heat pump

1 - heat exchanger; 2 - earth ground; 3 - pumps; 4 - heat pump; 5 - heat consumer.

It has been elaborated in $[7,8]$, that the addition of $\mathrm{Al}_{2} \mathrm{O}_{3}$ particles to the base fluid increases the heat transfer coefficient, while the friction coefficient decreases [9]. The average heat transfer coefficient of the ethylene glycol-A12O3 fluid comparing to water$\mathrm{Al}_{2} \mathrm{O}_{3}$ increases with an increase nanoparticle concentration, and at high concentrations it is about $17 \%$ $[10,11]$.

One of the factors affecting the efficiency of adding nanoparticles to the base fluid is their size. As described in [12], when the particle size of $\mathrm{Al}_{2} \mathrm{O}_{3}$ is $13 \mathrm{~nm}$, the thermal conductivity coefficient increases by an average of $30 \%$ compared to the base fluid, and for particle size equal to $40 \mathrm{~nm}$, the thermal conductivity increases by $10 \%$. Adding $10 \mathrm{~nm}$ particles with a volume concentration of $0.3 \%$ increase the thermal conductivity of a nanofluid up to $40 \%$ [13].

For modeling, it is necessary to define the relation of thermal conductivity and viscosity with respect to the volume concentration of nanoparticles. As described in [14-16], with an increase of the volume concentration, 
the viscosity and thermal conductivity are also increasing.

All studies described above were made for low volumetric concentrations and particle sizes. This paper is dedicated to evaluate the effect of adding $150 \mathrm{~nm}$ aluminum oxide nanoparticles with a volume concentration of $1,2,5,6 \%$ on the heat generation of a vertical geothermal heat exchanger.

\section{Materials and methods}

In this study, a model of a vertical geothermal doublepipe heat exchanger was used. The height of the heat exchanger is equal to $1.5 \mathrm{~m}$, the outer pipe is $219 \times 7.7$ $\mathrm{mm}$, the inner pipe is $180 \times 16.2 \mathrm{~mm}$.

A vertical heat exchanger has several benefits as compared to the horizontal one. It can be installed anywhere and requires less space.

The working fluid enters the inner pipe then passes into the annulus formed by the inner and outer pipes. While circulating through annular space, the working fluid gains heat from the ground. It was assumed that the volumetric flow rate is equal to $0.001 \mathrm{~m}^{3} / \mathrm{s}$, the initial velocity of the working fluid entering the heat exchanger is $0.059 \mathrm{~m} / \mathrm{s}$.

A $35 \%$ ethylene glycol solution with aluminum nanoparticles at initial temperature of $6^{\circ} \mathrm{C}$ was used as working fluid. The setpoints (no nanoparticles) are in accordance with the manual of the heat pump.

Typical values for ethylene glycol and $\mathrm{Al}_{2} \mathrm{O}_{3}$ used in the simulation are presented in Tab. 1.

Table 1. Thermophysical properties of ethylene glycol [17] and $\mathrm{Al}_{2} \mathrm{O}_{3}$.

\begin{tabular}{|l|c|c|}
\hline \multicolumn{1}{|c|}{ Parameters } & $\begin{array}{c}\text { Ethylene } \\
\text { glycol }\end{array}$ & $\mathrm{Al}_{2} \mathrm{O}_{3}$ \\
\hline Density $\rho, \mathrm{kg} / \mathrm{m}^{3}$ & 1045 & 3970 \\
\hline Heat capacity $c, \mathrm{~J} /(\mathrm{kg} \cdot \mathrm{K})$ & 3575 & 775 \\
\hline $\begin{array}{l}\text { Thermal conductivity, } \\
\mathrm{W} /(\mathrm{m} \cdot \mathrm{K})\end{array}$ & 0.4584 & 40 \\
\hline Kinematic viscosity, $\mathrm{m}^{2} / \mathrm{s}$ & $6.29 \cdot 10^{-6}$ & - \\
\hline Dynamic viscosity, $\mathrm{Pa} \cdot \mathrm{s}$ & $65.506 \cdot 10^{-4}$ & - \\
\hline
\end{tabular}

The density of nanofluid corresponding to densities of the base fluid $\rho_{\text {eth }}$ and nanoparticles $\rho_{A l 2 O 3}$ is calculated as follows

$$
\rho_{n f}=(1-\varphi) \cdot \rho_{e t h}+\varphi \cdot \rho_{\mathrm{Al}_{2} \mathrm{O}_{3}}
$$

where $\varphi$ is the volume fraction of particles.

Heat capacity and relative thermal conductivity of nanofluid are represented by equations [16]

$$
\begin{gathered}
c_{n f}=(1-f) \times c_{e f}+f \times c_{\mathrm{Al}_{2} \mathrm{O}_{3}} \\
k_{r}=1+\left(0.019+0.00383 \beta \gamma \sqrt{\varphi B^{\circ}}\right.
\end{gathered}
$$

where $f$ - mass particle concentration, $\beta c=\rho_{p} / \rho_{f}, \rho_{p}$, $\rho_{f}$ are the density of the nanoparticle and base fluid respectively, $B^{0}=d_{p} / \sigma, d_{p}, \sigma$ are nanoparticle size and effective size of the base fluid molecule.

The dynamic viscosity can be estimated by Brinkman's expression as:

$$
\mu_{n f}=\frac{\mu_{e t h}}{(1-\varphi)^{2.5}}
$$

The thermophysical data of nanofluids with respect to various concentrations of nanoparticle at an initial temperature of $6{ }^{\circ} \mathrm{C}$, calculated by Eq. (1-4) are presented in Tab. 2 .

To simulate the operation of the heat exchanger, the STAR-CCM + CFD application was used, which allows to numerically solve the Navier-Stokes equations. To take into account the multiphase nature of the working fluid, the Lagrange method is used. The equation of continuity has the form

$$
\nabla \mathbf{u}=0
$$

The momentum conservation equation is

$$
\rho\left(\frac{\partial \stackrel{\mathrm{r}}{u}}{\partial t}+\stackrel{\mathrm{r}}{u} \nabla \stackrel{\mathrm{r}}{u}\right)=-\nabla p+\mu_{e t h} \nabla^{2} \stackrel{\mathrm{r}}{u}-f_{p, \Sigma}
$$

where $u$ is the velocity of the carrier phase (in our case, ethylene glycol); $p$ is the pressure; $\mu_{\text {et }}$ is the dynamic viscosity of the carrier phase; $f_{p, \Sigma}$ is the total drag force of particles located in one computational cell. $f_{p, \Sigma}$ is defined as

$$
f_{p, \Sigma}=\sum f_{p, i}
$$

The drag force is defined as:

Table 2. Thermo physical properties of nanofluid.

\begin{tabular}{|l|c|c|c|c|}
\hline \multirow{2}{*}{ Parameter } & \multicolumn{4}{|c|}{ Volume concentration $\boldsymbol{\varphi , ~ \%}$} \\
\cline { 2 - 5 } & $\mathbf{1}$ & $\mathbf{2}$ & $\mathbf{5}$ & $\mathbf{6}$ \\
\hline Density, $\mathrm{kg} / \mathrm{m}^{3}$ & 1074 & 1103 & 1191 & 1220 \\
\hline Heat capacity, $\mathrm{J} / \mathrm{kg} \cdot \mathrm{K})$ & 3472 & 3374 & 3108 & 3029 \\
\hline Thermal conductivity, $\mathrm{W} /(\mathrm{m} \cdot \mathrm{K})$ & 0.483 & 0.493 & 0.513 & 0.518 \\
\hline Kinematic viscosity, $\mathrm{m}^{2} / \mathrm{s}$ & $6.253 \cdot 10^{-6}$ & $6.244 \cdot 10^{-6}$ & $6.25 \cdot 10^{-6}$ & $6.265 \cdot 10^{-6}$ \\
\hline Dynamic viscosity, $\mathrm{Pa} \cdot \mathrm{s}$ & 0.006717 & 0.006890 & 0.007447 & 0.007646 \\
\hline
\end{tabular}




$$
f_{p, i}=\frac{\pi}{8} \cdot d_{p, i}^{3} \cdot C_{D, i} \cdot \rho \cdot\left(\stackrel{\mathrm{r}}{u}-\stackrel{v}{v}_{i}\right)\left|u^{\mathrm{r}}-\stackrel{v}{v}_{i}\right|,
$$

where $C_{D, i}$ is the coefficient of resistance, which can be estimated by Schiller-Neumann's formula [19].

The number of calculated cells is 746584 . The basic size of the grid cell is $10 \mathrm{~mm}$ (Fig. 2).

To account for two-phase flow, the Lagrange method was used and represented by equations:

$$
\begin{gathered}
\left(\frac{\pi}{6}\right) d_{p}^{3} \rho_{p} \cdot \frac{d u_{p, i}^{\mathrm{r}}}{d t}=f_{p, i} \\
\frac{d\left(\stackrel{\mathrm{r}}{\omega}_{p, i} I_{i}\right)}{d t}=\stackrel{\mathrm{r}}{T}_{p, i} \\
\frac{\pi}{6} d_{p}^{3} \rho_{p} C_{p} \cdot \frac{d T_{p, i}}{d t}=q_{f, p}
\end{gathered}
$$

Equations (8-10) describe the motion of a "virtual" particle with a diameter $d_{p}$, its rotation and interphase heat transfer between the particles and the base fluid (Ranz-Marshall formula) [19].

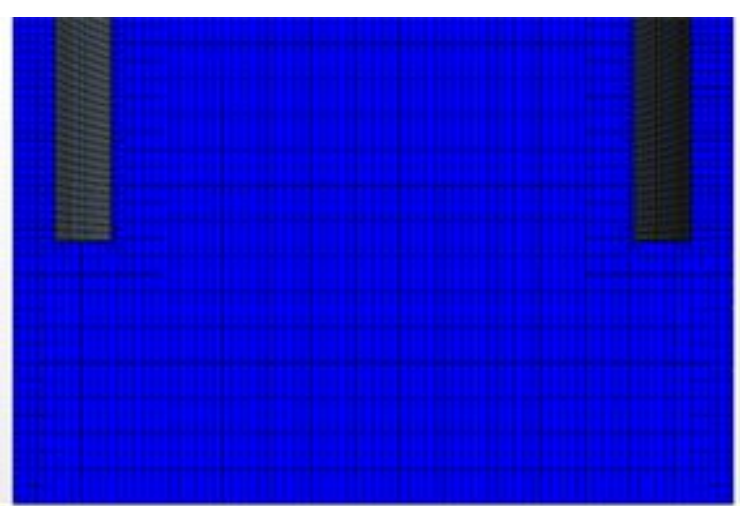

Fig. 2. Grid model for calculating a heat exchanger.

The following conditions were assumed for modeling:

1) To save computer power, the movement of the working fluid starts $0.15 \mathrm{~m}$ from the bottom;

3) The temperature of the outer wall and bottom is $t_{\text {wall }}=5^{\circ} \mathrm{C}$;

4) To reduce the hydraulic resistance in the heat exchanger, the distance from the bottom to the outlet section of the inner tube is $74 \mathrm{~mm}$;

5) The flat section ( $T$ _out_sense) was assumed at a height of $1.495 \mathrm{~m}$, according to which a report file was created, determining the average outlet temperature $T_{\text {out }}$.

The boundary conditions are shown in Fig. 3.

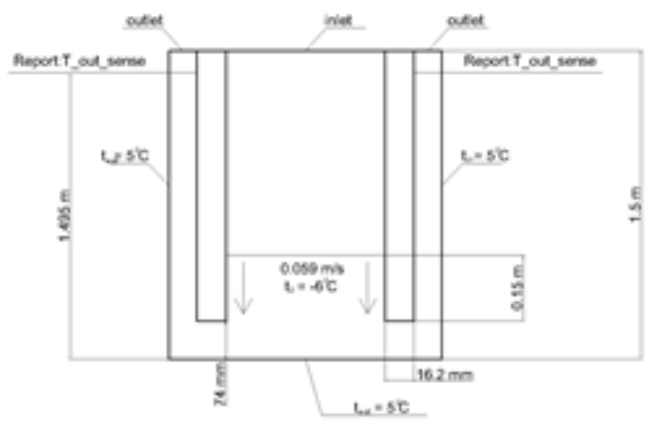

Fig. 3. Boundary conditions for modeling (T_out_sense section was created to determine the temperature at the outlet from the heat exchanger).

The thermal power output of the heat exchanger is calculated as:

$$
\left.Q=G_{v} c_{p}\left(T_{\text {out }}-T_{\text {in }}\right)\right)
$$

\section{Results}

To analyze the effect of using nanofluid on heat exchanger efficiency, the initial calculation was made for the base fluid. The results are presented in Tab. 3 .

Table 3. Results of numerical simulation of a ground heat exchanger without nanoparticles.

\begin{tabular}{|c|c|}
\hline Parameter & Result \\
\hline Outlet temperature, ${ }^{\circ} \mathrm{C}$ & -4.65 \\
\hline Temperature difference, ${ }^{\circ} \mathrm{C}$ & 1.35 \\
\hline Thermal power, $\mathrm{W}$ & 5062.0 \\
\hline
\end{tabular}

Figures 4 and 5 shows the temperature distributions at the outlet and in the bottom part of heat exchanger for $2 \%$ volume particle concentration.
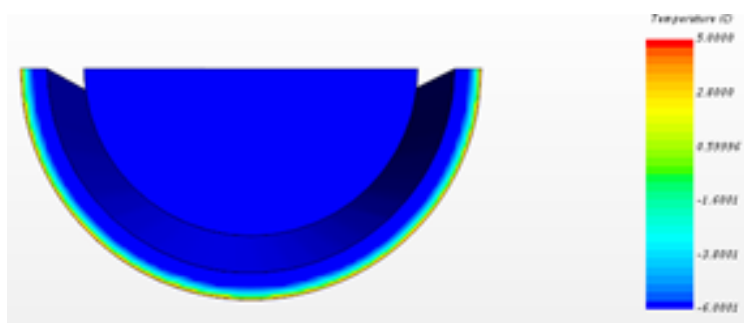

Fig. 4. Temperature distribution of ethylene glycol with $\mathrm{Al}_{2} \mathrm{O}_{3}$ nanoparticle at the outlet of the heat exchanger.

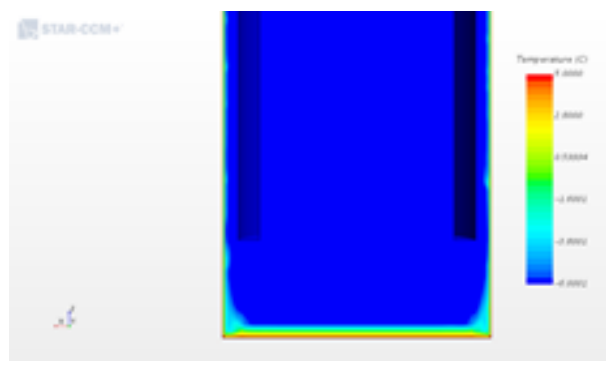

Fig. 5. Temperature distribution of ethylene glycol c nanoparticle $\mathrm{Al}_{2} \mathrm{O}_{3}$ in the bottom part of the heat exchanger. 
Table 4 and Fig. 6 shows the results of calculating the model using nanoparticles.

Table 4. Results of numerical simulation of a ground heat exchanger with the addition of nanoparticles.

\begin{tabular}{|l|c|c|c|c|}
\hline \multirow{2}{*}{ Parameter } & \multicolumn{4}{|c|}{ Volume concentration $\boldsymbol{\varphi}, \mathbf{0}$} \\
\cline { 2 - 5 } & $\mathbf{1}$ & $\mathbf{2}$ & $\mathbf{5}$ & $\mathbf{6}$ \\
\hline $\begin{array}{l}\text { Outlet } \\
\text { temperature, }{ }^{\circ} \mathrm{C}\end{array}$ & -4.58 & -4.53 & -4.50 & -4.54 \\
\hline $\begin{array}{l}\text { Temperature } \\
\text { difference, }{ }^{\circ} \mathrm{C}\end{array}$ & 1.42 & 1.47 & 1.50 & 1.46 \\
\hline $\begin{array}{l}\text { Thermal power, } \\
\text { W }\end{array}$ & 5412.2 & 5712.1 & 6184.6 & 6090.2 \\
\hline
\end{tabular}

The obtained results show the increase of temperature difference of the nanofluid in comparison with the base fluid heating. This is due to enhance of the thermal conductivity when nanoparticles are added. When the concentration is more than $5 \%$ temperature difference decreases.

Temperature increase can be related with the deposition of particles that remain on the walls, thereby heating up more intensively and transferring heat to the carrier phase.

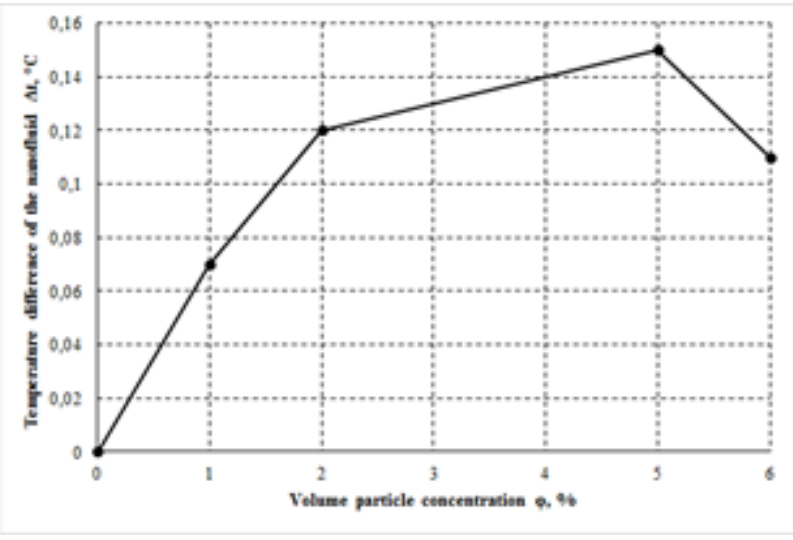

Fig. 6. Dependence of the increase in heating of the coolant on the added concentration of nanoparticles.

\section{Conclusion}

A simulation of a vertical geothermal heat exchanger with a nano fluid (ethylene glycol- $\mathrm{Al}_{2} \mathrm{O}_{3}$ ) at various volumetric concentrations has been carried out. Based on the results of numerical modeling, the dependences of working fluid outlet temperature and the heat exchanger capacity with respect to the concentration of nanoparticles are determined. Further research is required with the use of nanoparticles of different composition and the refinement of the model taking into account the distribution of soil temperature along with the height.

This study was supported by the Russian Science Foundation (Project No. 19-79-10083).

\section{References}

1. Peter Sorknæs, Poul Alberg Østergaard, Jakob Zinck Thellufsen, Henrik Lund, Steffen Nielsen, Søren Djørup, Karl Sperling, The benefits of 4th generation district heating in a $100 \%$ renewable energy system, Energy 213 (2020), DOI: 10.1016/j.energy.2020.119030.

2. S. Werner, International review of district heating and cooling, Energy, 137 (2017), pp. 617-631.

3. Vasil'ev G.P,, "Geothermal heat pump systems for heat and cool supply of buildings and structures ". https://insolar.ru/biblioteka/nashi-publikatsii/lib_7/

4. 1. Sui D., Langaker V.H., Yu Z., Investigation of Thermophysical Properties of Nanofluids for Application in Geothermal Energy, (2017) Energy Procedia, 105 , pp. 5055-5060.

5. Wu, Siyuan \& Dai, Yuchao \& Li, Xiaolu \& Oppong, Francis \& Xu, Cangsu. (2018). A review of ground-source heat pump systems with heat pipes for energy efficiency in buildings. Energy Procedia. 152. 413-418. 10.1016/j.egypro.2018.09.167.

6. Storch, Braune, Gross, et al. Performance of a geothermal heat pipe using propane[C]// Minsk Int. Seminar "heat Pipes, Heat Pumps, Refrigerators, Power Sources. 2011.

7. A. Moghadassi, E. Ghomi, F. Parvizian, A numerical study of water based $\mathrm{Al} 2 \mathrm{O} 3$ and Al2O3$\mathrm{Cu}$ hybrid nanofluid effect on forced convective heat transfer, Int. J. Therm. Sci. 92 (2015) 50-57.

8. R.K. Shah, Thermal entry length solutions for the circular tube and parallel plates, in: Proceedings of Third National Heat Mass Transfer Conference, Indian Institute of Technology, Bombay, 1975, p. 1 (Paper No. HMT-11-75).

9. S. Suresh, K.P. Venkitaraj, P. Selvakumar and M. Chandrasekar, Effect of $\mathrm{Al} 2 \mathrm{O} 3-\mathrm{Cu} /$ water hybrid nanofluid in heat transfer, Exp. Therm. Fluid Sci., 38 (2012), pp. 54-60.

10. S. El Becaye Maïga, S.J. Palm, C.T. Nguyen, G. Roy and N. Galanis, Heat transfer enhancement by using nanofluids in forced convection flows, Int. J. Heat. Mass Trans., 26 (4) (2005), pp. 530-546.

11. H. Masuda, A. Ebata, K. Teramae and N. Hishinuma, Alteration of thermal conductivity and viscosity of liquid by dispersing ultra-fine particles (dispersions of - $\mathrm{Al} 2 \mathrm{O} 3, \mathrm{SiO} 2$, and $\mathrm{TiO} 2$ ultra-fine particles), Netsu Bussei (Japan), 4 (1993), pp. 227 233.

12. S. Lee, S.U.S. Choi, S. Li and J.A. Eastman, Measuring thermal conductivity of fluids containing oxide nanoparticles, J. Heat Transfer, 121 (1999), pp. 280-289.

13. J.A. Estman, S.U.S. Choi, S. Li, W. Yu and L.J. Thomson, Anomalously increased effective thermal conductivities of ethylene glycol based nanofluid containing copper nanoparticles, Appl. Phys. Lett., 78 (2001), pp. 718-720. 
14. D. Ceottoa, V. Ya. Rudyak, Phenomenological Formula for Thermal Conductivity Coefficient of WaterBased Nanofluids, Colloid Journal, 2016, Vol. 78, No. 4, pp. 509-514.

15. M.I. Pryazhnikov, A.V. Minakov, V.Ya. Rudyak, D.V. Guzei, Thermal conductivity measurements of nanofluids, International Journal of Heat and Mass Transfer, Vol. 104, January 2017, pp. 1275-1282.

16. V.Ya. Rudyak, A.V. Minakov, Thermophysical properties of nanofluids, Eur. Phys. J. E (2018) 41: 15.

17. Teploobmennye apparaty kholodil'nykh ustanovok / G. N. Danilova, S. N. Bogdanov, O. P. Ivanov i dr. ; red. G. N. Danilova. - Izd. 2-e, pererab. i dop. - L. : Mashinostroenie, 1986. - $304 \mathrm{~s}$.

18. Brinkman, The viscosity of concentrated suspensions and solution, J. Chem. Phys., 20 (1952), pp. 571-581.

19. Crowe, C.T., Schwarzkopf, J.D., Sommerfeld, M., \& Tsuji, Y. (2011). Multiphase Flows with Droplets and Particles (2nd ed.). CRC Press. https://doi.org/10.1201/b11103. 